\title{
MINIMUM AGE DIFFERENCE AS A REQUISITE FOR ADOPTION
}

\author{
WALTER J. WADLINGTON, III*
}

\begin{abstract}
Recent incidents of abortive uses of adoption statutes have pointed up the possible need for a healthy change in our adoption laws: the inclusion of a required age difference between adopter and adoptee. The author urges that such a statutory requirement is necessary to more fully effectuate the idea that "adoption imitates nature," a postulate of adoption law originating in Roman jurisprudence and, so the author contends, underlying adoption law in this country. The article raises interesting questions concerning the very nature of adoption, the function which it serves in our society, and the possible policy differences between minor and adult adoptions.
\end{abstract}

\section{INTRODUGTION}

It is settled that a man cannot adopt another person older than himself, for adoption imitates nature, and it would be unnatural for a son to be older than his father. $\dagger$

FEW YEARS AGO a husband in Kentucky contributed greatly
to the legal lore of his state and perhaps of the entire United
States when he adopted his wife. Despite arguments that this
was not in accord with the basic purpose of adoption in this country
and that it created something which looked suspiciously like an in-
cestuous relationship by operation of law, the highest court of Ken-
tucky upheld the adoption's legal validity. Although we might be
tempted to dismiss the case as one of those occasional aberrations
which will occur only infrequently, this is in fact not the case.

* A.B. 1951, Duke University; LL.B. 1954, Tulane University. Professor of Law, University of Virginia.

†INstrutes 1.11.4 (Moyle transl.). The full Latin text is "Minorem natu non posse maiorem adoptare placet: adoptio enim naturam imitatur et pro monstro est, ut maior sit filius quam pater. . .." MOYLE, IMPERATORIS IUSTINIANI INSTITUTIONES 140 (1923).

${ }^{1}$ Bedinger v. Graybill's Ex'r \& Trustee, 302 S.W.2d 594 (Ky. 1957). The deceased husband was the life beneficiary of a trust, the remainder of which was to pass to his "heirs at law," and to named charities if there were no heirs (presumably the wife qua wife would not quahify).

"In Wilson v. Johnson, 389 S.W.2d 634 (Ky. 1965), the remainder in a trust was left to the life beneficiary's "children." Shortly before his death, the life beneficiary adopted the two children of his deceased wife's former marriage, aged forty-eight and 
Even if it were, we should reflect upon it more carefully as an illustration of how our adoption statutes may be utilized for perhaps totally undesirable and totally unintended purposes. ${ }^{3}$ For example, if the logical (or illogical) progression ensues from this case and its progeny, the next probable step will be for someone to adopt his father or mother-or perhaps even a grandparent. The fact of relationship through consanguinity would seem to present no greater obstacle than relationship through affinity in most jurisdictions. ${ }^{4}$ And surely the problem of having a twenty-one-year-old father with a seventy-five-year-old child is no more objectionable socially than having a man legally married to his daughter, even in a society which still condemns incest and ostensibly imposes legal sanctions against the practice. ${ }^{5}$

As the previous paragraph indicates, the anomalous situations which can occur will generally be produced by adult adoptions. It is true that many of the underlying reasons for unusual adoptions do not lend themselves to adoption of minors; ${ }^{6}$ it is also true that

fifty-two. In Pennington v. Citizens Fidelity Bank \& Trust Co., 390 S.W.2d 671 (Ky. 1965), "at age 74, Dudley W. Pennington, was adopted by his childless wife, age 71 ," in order to save a similar remainder in a trust. In the Master of Estate of Comley, 90 N.J. Super. 498, 218 A.2d 175 (Gloucester County Ct. 1966), involved a trust fund equal portions of which were to be distributed to the "children" of the settlor's brother at age thirty-five. The brother adopted the plaintiff when she was thirty-six.

In the above three cases, the courts held that "children" should be construed as including only natural-born children and persons adopted as minors.

The Kentucky legislature was evidently unconcerned with the problem when they amended their adoption statute after the Bedinger case. They lowered the age at which one could be adopted as an adult from twenty-one to eighteen years but added no proscription on husband-wife adoptions. See Ky. REv. STAT. ANN. $\$ 405.390$ (Supp. 1965).

See note 6 infra.

- Several states do specifically exclude adoptions between certain classes of persons. Connecticut, in its statute providing for adoption of adults, forbids one from adopting his "wife, husband, brother, sister, uncle or aunt." CONN. GEN. STAT. ANN. § 45-67 (Supp. 1965). Massachusetts has a similar provision applicable to adoption in general. MASS. ANN. LAws ch. 210, $\$ 1$ (1955).

- Nevada has found both alternatives objectionable enough to justify preventive legislation. In its provision on adoption of adults it requires that the adopter be older than the adoptee; once this requirement has been met he can adopt any adult other than his spouse. NEv. REv. STAT. $\$ 127.190$ (1963). And see the more inclusive statutes in note 4 supra.

Marriage or sexual relations between a parent and his adopted child are generally considered to be outside most incest laws (unless there is a pre-existing blood relationship) because relationship by adoption is distinguished from relationship through either affinity or consanguinity. For a discussion of the confusion on this subject, see Wadlington, The Adopted Child and Intra-Family Marriage Prohibitions, 49 VA. L. REv. 478 (1963).

- With a little bit of imagination it is possible to come up with a number of purposes (often questionable) for adoption of an adult. The most obvious one has already been mentioned: to acquire a legal heir rapidly in order to benefit from the pro- 
the procedural obstacles will ordinarily be greater in this latter situation. ${ }^{7}$ Nevertheless, the danger of illegitimate use of adoption laws even where a minor is the adoptee compels us to consider this facet of the problem as well.

Specific legislation barring adoption of close relatives ${ }^{8}$ or forbidding the use of adoption for named purposes is, of course, one possible method of attacking these problems. Abolition of the institution of adult adoptions would be at least a partial solution. ${ }^{\circ}$ But a less drastic alternative, one which is admittedly not a panacea, but which also would produce healthy effects beyond the immediate problem, is to require a minimum age difference between adopter and adoptee in all cases.

Some states and many foreign countries already provide for such a mandatory age variation. The purpose of this article is to examine the various laws requiring or failing to require a minimum age difference between adopter and adoptee, along with the conflicting social interests involved, so that it can be determined whether further safeguards are desirable or necessary in our own state laws at this time.

\section{I}

The Crvil Law Approach

In most civilian jurisdictions the Roman law principle of adoptio naturam imitatur (adoption imitates nature) has led to legislative safegnards which prevent an adoption if the person to be adopted is not old enough to be the adopter's natural child. These provisions and this principle have origins in Justinian's time or before, and the discussion of the civil law approach therefore must begin with a review of the applicable Roman law.

visions of a known testamentary or trust provision. Tax considerations are another possibility. Further, a man might well adopt his concubine in order to justify living in the same house with her and to constitute her as an heir, all without what might seem to him some of the undesirable aspects of the marriage relationship, such as the necessity of grounds for divorce and the possibility of alimony should he tire of her company. Or a parent who wishes to cut down the size of any forced or statutory share of an estate which might go to his blood children might well adopt a number of others out of spite. Further, in a day when the plain old "kook" has come into his own, one oddball might simply adopt a flock of others for the sheer hell of it.

'The requisite procedures frequently are quite different for adult and minor adoptions, Compare Cal. Civ. Code $\$ 226$ with Cal. Civ. Code $\$ 227$ p. Compare Fra. STAT. ANn. \$ 72.12-.15 (1964) with Fla. STAT. ANn. \$ 72.34-.37 (1964). Compare Tex. Rev. Civ. Stat. AnN. art. 46a (1959) with Tex. Rev. Grv. Stat. AnN. art. 46b-1 (1959).

${ }^{8}$ A few states have so provided. See notes 4 and 5 supra.

' See Wadlington, Adoption of Adults in Louisiana, 40 TUL. L. REv. 1 (1965). 


\section{A. The Roman Law Background}

The institution of adoption in Roman law is generally considered as having existed primarily for the benefit of the adopter or his family. ${ }^{10}$ It assumed two basic forms, adoptio ${ }^{11}$ and adrogatio..$^{12}$ In the former, the person adopted was alieni iuris (subject to paternal authority), while in the latter the adopted-or, more properly, adrogated-party was sui iuris (not subject to paternal authority)..$^{13}$ By the time of Justinian both adoptio and adrogatio were governed by adoptio naturam imitatur. ${ }^{14}$ Accordingly, a castratus could not adopt ${ }^{15}$ (though an adopter need not be married because procreation could take place outside of marriage, assuming that the parties were properly equipped ${ }^{16}$ ), and the adopter had to be sufficiently older than the adopted person to have been capable of procreating him. ${ }^{17}$ The latter requirement seems to be of relatively late development. Previously, Gaius had made a reference to "the dispute whether a younger can adopt an older person,"18 and there is evidence of an accusation by Cicero that Clodius was adrogated by someone younger than he. ${ }^{19}$ Nevertheless, by the time of Modestinus it seems clear that in either adoptio or adrogatio the party adopting had to be at least eighteen years older than the party adopted, ${ }^{20}$ and this rule was included in the Institutes of Justinian. ${ }^{21}$ It should be noted that under Roman law normally only a male could adopt because a woman was incapable of patria potestas (paternal authority). ${ }^{22}$ This rule was gradually relaxed to allow adoption by women in certain limited cases (for example, when a mother had lost all

\footnotetext{
${ }^{10}$ Among the various personal ends served by adoption in Rome were the continuance of the res sacra or family religious rites (see NichoLs, AN INTRODUction to ROMAN LAW 77 (1962)), and the selection by an emperor of his successor (see WolfF, Roman Law 17, 45 (1951)).

11 See Buckland, A Textbook of Roman Law $121-28$ (3d rev. ed. 1963).

1s See $i d$, at 124 .

${ }^{13}$ The older of the two was adrogatio. Because of the sui iuris status of the party adrogated, it also had the most sweeping effects, since one family was in effect extinguished through merger with another.

14 INSTITUTES 1.11.1,.4.

${ }^{25}$ INSTITUTES 1.11.9.

${ }^{10}$ BUCKLAND, op. cit. supra note 11 , at 123.

${ }^{27}$ INSTITUTES 1.11.4; see BuCKLAND, op. cit. supra note 11, at 123.

18 GaIUS 1.106.

${ }^{\circ}$ Cicero, de Domo Sua ad Pontifices Oratio 13-14 (Nisbet ed. 1939); Moyle, IMPERATORIS IUSTINIANI INSTTTUTIONES $\$ 4$, at 140 (1923); Huard, The Law of Adoption: Ancient and Modern, 9 VAND. L. Rev. 743, 744-49 (1956).

${ }^{20}$ Digest 1.7.40.1.

21 INSTITUTES 1.11.5.

22 INSTITUTES 1.11.10.
} 
her children ${ }^{23}$ ), but it seems clear that the specifically required age difference of eighteen years was based on the normal difference between father and child rather than mother and child, with eighteen being the latest date at which the male would be expected to reach maturity. ${ }^{24}$

\section{B. The Civil Law Today}

Although the Roman law of adoption was by no means carried directly into modern civil law jurisdictions, ${ }^{25}$ it certainly served as an important influence. Its "adoption imitates nature" principle has continued at least to the extent of requiring a minimum age difference between adopter and adoptee. Furthermore, the basic purpose of adoption in most of the modern civil law jurisdictions still seems to be satisfaction of the needs of the adopter-or at least the adopter's needs are considered as important as those of the adoptee..$^{20}$ This is illustrated by the frequent legislative inclusion of a fairly high minimum age for the adopter, independent of the requirement of a minimum age difference. A few of the major civil law jurisdictions will be discussed to illustrate the consensus today.

\section{France}

The institution of adoption had almost disappeared in France by the time of the French Revolution, ${ }^{27}$ but in 1792 adoption was

\footnotetext{
${ }^{23}$ Ibid; see Jolowicz, Roman Foundations of Modern Law 196 (1957).

${ }^{24}$ Institutes 1.11.4. It should be noted that under Roman law a person could be adopted not just as a son but as a grandson or even a great grandson. INSTITUTES 1.11.5. At least one eminent Roman law scholar has stated that in such instances a proportionate increase in the required age variation would be made in consideration of the more remote degree. BUCKLAND, op. cit. supra note II, at 123.

${ }^{25}$ See Jolowicz, op. cit. supra note 23, at 196.

${ }^{20}$ The approach to adoption in France affords a good example of this point. See amos \& Walton, Introduction to French Law 78 (2d ed. 1963). The debates over reintroduction of the institution of adoption into the Givil Code illustrate some of the mixed feelings about its purpose. See 10 Fenet, Recueil Complet des Travaux Preparatorrs dU Code Civil 247 (1827). Particularly harsh were the words of $M$. Tronchet that 'l'adoption n'est plus qu'un moyen d'eluder les probibitions par lesquelles la loi limite, surtour à l'égard des enfans naturels, la faculté de disposer, ou une manière de satisfaire Ja vanité de ceux qui désirent perpétuer leur nom et leur famille." $I d$. at 255-56.

Even today adoption in France is revocable under certain circumstances, and the adopter remains a member of his natural family in many respects. See CoDe CiviL arts. 354-67 (Fr. 66th ed. Dalloz 1966). However, since World War I there has been more of a tendency toward viewing and utilizing adoption as a method for accomplishing the socially desirable result of caring for homeless infants. This is evidenced by the introduction of the new institution of adoptive legitimation, discussed in text accompanying notes $38-42$ infra.

${ }^{27}$ See Brissaud, A History of French Private Law 218 (1912); 6 Demolombe, Cours de Code Napoleon, Tratté de r'Adoption 2-3 (1875).
} 
included in the general plan of laws, ${ }^{28}$ and in 1803 it was incorporated into the Civil Code ${ }^{29}$ in limited form. Only persons older than fifty could adopt, and the adoption could not take place until the party to be adopted had reached majority. ${ }^{30}$ Though the basic purpose of adoption was primarily to perpetuate family lines for childless parents, ${ }^{31}$ the drafters still recognized that the artificially created parent-child relationship should nevertheless conform to biological reality, and an age difference of fifteen years between the adopter and the adopted party was made mandatory. ${ }^{32}$

In the modern French law, minors may be adopted, ${ }^{33}$ and the minimum age of the adopting party has been reduced to thirtyfive. ${ }^{34}$ But the required age difference of fifteen years between adopter and adoptee has been maintained, ${ }^{35}$ with several exceptions. If the person to be adopted is the child of the adopter's spouse, then the required age difference is reduced to ten years. ${ }^{36}$ And there is provision for a special reduction of the age variation, or even a complete dispensation from its provisions, by the chief of state. ${ }^{37}$

Because adoption in French law is still subject to limitations which make it fall unnecessarily short of the normal parent-child relationships, ${ }^{38}$ a new institution known as adoptive legitimation was added in $1939 . .^{30}$ In its present form, the party to be adopted cannot be over the age of seven, ${ }^{40}$ and the adopting parties must be a married couple.41 In this form of adoption, which comes much closer to our own in approach, the same age differential requirements as in the regular French adoption provisions are applicable. ${ }^{42}$

${ }^{28}$ The Law of January 18, 1792, and the legislation following it are outlined in Demolombe, op. cit. supra note 27, at 3-7; 1 Planiol, Traité ElÉmentaire de Droit Givic Nos. 1570-70A (1959).

${ }^{\circ}$ CODE CrviL arts. 343-52 (Fr. 1803).

${ }^{30}$ CoDE Givil arts. 343, 346 (Fr. 1803).

${ }^{31}$ See Amos \& Walton, op. cit. supra note 26, at 78; Planiol, op. cit. supra note 28, at No. 1569 .

${ }^{32}$ Code Crvil art. 343 (Fr. 1803).

${ }^{33}$ CoDe Crvil art. 343 (Fr. 66th ed. Dalloz 1966).

3t Code Crvil art. 344 (Fr. 66th ed. Dalloz 1966).

${ }^{35}$ Ibid.

so Ibid.

87 Ibid.

${ }^{88}$ For example, the adoption may be revoked under grave circumstances, according to article 367 , and for many purposes the adoptee remains a member of his original family. See Amos \& WaLton, op. cit. supra note 26, at 78-79.

${ }^{30}$ Code Crvil arts. 368-70 (Fr. 66th ed. Dalloz 1966); see Amos \& Walton, op. cit. supra note 26 , at 79 .

${ }^{\circ}$ Code Crvil art. 368 (Fr. 66th ed. Dalloz 1966).

11 Ibid.

19 Ibid. 


\section{Other Countries}

Under Italian law, the adopter must be at least fifty years old and have no living descendants, ${ }^{43}$ and he must be at least eighteen years older than the adopted party. ${ }^{44}$ In special circumstances, the age of the adopter may be reduced to forty and the required age difference to sixteen years. ${ }^{45}$

The Swiss Civil Code requires the adopter to be forty years old and without legitimate descendants. ${ }^{46} \mathrm{He}$ also must be at least eighteen years older than the adopted party. ${ }^{47}$

Unless the person to be adopted is the natural child of either of the spouses seeking to adopt him, a difference of twenty years in age is required under the laws of Quebec.48

Under its new Civil Code, Greece provides both for a minimum age of fifty for the adopter ${ }^{49}$ and a minimum age difference of eighteen years between adopter and adoptee. ${ }^{50}$

Although the Roman law requirement of a difference of eighteen years was found in Las Siete Partidas, ${ }^{51}$ the Spanish Civil Code of 1889 lowered this to fifteen years. ${ }^{52}$

\section{A Summary}

In a 1956 United Nations study on adoption, ${ }^{53}$ which included a number of the previously mentioned countries, it was found that approximately two-thirds of the twenty-odd jurisdictions which were examined (including four states in this country and three Canadian provinces ${ }^{54}$ ) required an age differential between adopter and

\footnotetext{
$\$ 3$ Códice Civile art. 291 (Italy 1953).

"Ibid.

${ }^{45}$ The authority to grant such an exception is vested in the Court of Appeals. Códice Crvile art. 291 (Italy 1953).

10 Code Crvil art. 264 (Swit. Rossel 1957).

"Ibid.

${ }^{48}$ QUe. Rev. STAT. 1941, c. 324, $\$ 4$.

10 Civir Code art. 1568 (Greece 1956).

${ }^{50}$ Crvil CoDe art. 1574 (Greece 1956).

s2 Las Siete Partidas 4.16.2 (Spain CCH 1931).

${ }^{52}$ CrviL CODE art. 173 (Spain 1889). In discussing this requirement and its origin in the "adoption imitates nature" principle, Manresa points out that Spanish law at that time regarded twelve as the age of puberty for females and fourteen for males. See 2 Manresa, Comentaries al Código Civil Español 71 (1907).

${ }^{53}$ Comparative Analysis of Adoption Laws, U.N. Doc. No. ST/SOA/30 (1956).

${ }^{54} I d$. at 16. The countries included in the study were Denmark, France, Greece, Northern Ireland, Poland, Switzerland, the U.S.S.R., the United Kingdom, and Yugo. slavia, in Europe; Argentina, Bolivia, Guatemala, Peru, and Uruguay, in Latin America. In North America three Canadian provinces (Quebec, Ontario, and Saskatchewan) were studied, along with four states of this country (Alabama, California, Michigan, and New York).
} 
adoptee. The lowest fixed age difference among those jurisdictions which had such restrictions was the ten year requirement of California. ${ }^{55}$

II

\section{The English Approach}

One cannot speak of a common law approach to adoption, because the common law had no such institution as either we or the Romans have used and understood the term. ${ }^{58}$ The Adoption of Children Act, 1926,57 which first brought adoption to England, provided only for the adoption of infants and required that an adopter be at least twenty-five years old ${ }^{58}$ and twenty-one years older than the adoptee.59 If the adopter and the infant were "within the prohibited degrees of consanguinity," cretion to disregard the requirement of a minimum age difference. This provision was construed judicially to mean that the court's discretion could be exercised only when the parties were within the degree of blood relationship prescribed for marriage, and without regard to sex. ${ }^{61}$ Thus a mother could adopt her illegitimate daughter less than twenty-one years her junior, but the mother's husband could not join in the adoption unless he were the natural father or twenty-one years older than the infant. This anomalous situation was remedied by legislation permitting adoption jointly by two spouses without an age differential requirement if one of the spouses was either the natural mother or putative father. ${ }^{62}$

In 1958 the required twenty-one-year age difference was eliminated. ${ }^{63}$ However, the structure of the present act still assures that there will ordinarily be a minimum age difference of at least five years, and generally more, since the adopter must be either $(a)$ the

${ }^{55}$ CAL. Grv. CODE $\$ 222$.

${ }^{B O}$ For the background and development of the English law of adoption, see BromLey, FAMILY LAW 385 (2d ed. 1962); James, The Illegitimate and Deprived Child: Legitimation and Adoption, in A CENTURY OF FAMILY LAW 39, 45-55 (Graveson \&. Crane eds. 1957).

${ }^{57}$ Adoption of Children Act, 1926, 16 \& 17 Geo. 5, c. 29.

${ }^{88}$ Adoption of Children Act, 1926, 16 \& 17 Geo. 5, c. 29, $\$ 2$ (I) (a).

${ }^{50}$ Adoption of Children Act, 1926, 16 \& 17 Geo. 5, c. 29, § 2 (T) (b).

"Ibid.

${ }^{01}$ In re "C," [1938] Ch. 121 (1937).

${ }^{\circ 2}$ Adoption of Children (Regulation) Act, 1939, 2 \& 3 Geo. 6, c. 27, § 8. The amendment also added the specific proviso concerning adoption by the mother alone.

${ }^{\circ 3}$ The Adoption Act, 1950, 14 Geo. 6, c. 26, $\S 2$ (1) (a), had maintained the required age difference of twenty-one years. But the Adoption Act, 1958, 7 Eliz. 2, c. 5, greatly revised the language of $\S 2$ of the former acts, eliminating the required age difference. 
child's mother or father, $(b)$ a relative at least twenty-one years old, or $(c)$ a person twenty-five years or older. ${ }^{64}$ If the prospective adopters are a married couple adopting jointly, the minimum age requirement becomes unimportant if either is the mother or father of the child; and if condition (b) or (c) is met by one of the spouses, then the other need only be age twenty-one or more. ${ }^{65}$ The act still only applies to the adoption of infants.

\section{III}

The Historical Background in the United States

Because adoption is a creature of state law, it is not surprising to discover that there have been several different approaches to the problem of a required age difference between adopter and adoptee in this country. To a large extent we can explain these variations by examining the several statutes or draft proposals of adoption laws which have proved most influential on different groups of states. The chief such influences seem to have been (A) the civil law (primarily as received through French or Spanish influence), (B) the Massachusetts statute of 1851, (C) the Civil Code of New York, which was never adopted in that state, but which became an important legislative influence in the midwestern and far western states, and (D) the Uniform Adoption Act. Each of these four influences and its effect on the age differential problem will be considered separately.

\section{A. The Civil Law Influence}

At one time Louisiana and Texas adoption law bore a strong Spanish influence, as shown by some early cases which cited Las Siete Partidas. ${ }^{68}$ We may assume, therefore, that at that time a required age variation existed. ${ }^{67}$ But the modern law of both states has come a long way from the earlier Spanish law.

In Louisiana, adoption was specifically abolished by the Civil Code of $1808,{ }^{68}$ and a similar proscription was inserted in the Civil Code of $1825 .{ }^{69}$ Nevertheless, adoption could be effected during this

\footnotetext{
of Adoption Act, 1958, 7 Eliz. 2, c. 5, § 2 (1).

${ }^{\circ}$ Adoption Act, 1958, 7 Eliz. 2, c. $5 . \S 2$ (2).

${ }^{\circ}$ See, e.g., Vidal v. Commagère, 13 La. Ann. 516 (1858); Fuselier v. Masse, 4 La. 640 (1832); Teal v. Sevier, 26 Tex. 516 (1863).

or The eighteen-year age variation of the Roman law was carried into the Partidas. Las Siete Partidas 4.16.2 (Spain CCH 1931).

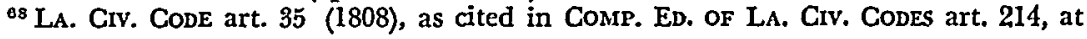
125 (1940).

(9 LA. Crv. Code art. 232 (1825), as cited in CoMp. Ed. of LA. Crv. Codes art. 214, at 125 (1940).
} 
period by special legislative action. ${ }^{70}$ In 1864 the state constitution was amended to permit general adoption legislation, ${ }^{71}$ and in 1865 specific adoption provisions were enacted. ${ }^{2}$ The Civil Code of 1870 contained an article setting forth requirements for adoption and the civil effects produced by it. ${ }^{73}$ Patterned to some degree after the French Civil Code of 1803,74 the Louisiana codal provision required that the adopter be at least forty years old and at least fifteen years older than the adoptee. In 1872, however, the legislature eliminated the required age difference in minor adoptions and provided that the adopter merely need be over the age of twenty-one..$^{75}$

The early adoption statutes enacted by Texas after its statehood ${ }^{76}$ betray some civil law infiuence and were so interpreted by the courts. ${ }^{77}$ There was, however, no minimum age nor age difference requirement.

Although early courts in various other jurisdictions sometimes suggested that Roman or Greek law was the source of adoption statutes in this country, ${ }^{78}$ this appears to be accurate only to the extent that we define adoption as an artificially created parent-child relationship. Except in the early law of Louisiana and Texas, there has been very little Roman law influence on adoption laws in the

\footnotetext{
${ }^{70}$ See, e.g., La. Acts 1860, No. 181; La. Acts 1837, No. 65.

${ }^{11}$ LA. ConsT. art. 117 (1864).

72 La. Acts, Ist Sess. 1865, No. 48.

${ }^{33}$ LA. REv. CIv. Cone art. 214 (1870).

74 CoDE Civil art. 343 (Fr. 1803).

${ }^{75}$ La. Acts 1872, No. 31. The requirement of a fifteen-year age difference remained in article 214 of the Civil Code until 1948, when it was eliminated by La. Acts 1948, No. 454. The age difference requirement probably remained in effect for adult adoptions during this time. However, the history of adoption of adults in Louisiana is extremely confused and there is some question whether it was even legally possible between 1870 and 1924. See Succession of Pizzati, 141 La. 645, 75 So. 498 (1917). An out-of-state adoption of an adult was attacked in Louisiana during this period on the ground that it had not been shown that the adopter and adoptee were more than fifteen years apart in age. The challenge was unsuccessful because of lack of evidence in the record as to the ages of the parties, and thus a possible public policy issue based on confiict of laws was avoided. Succession of Caldwell, I14 La. 195, 38 So. 140 (1905). See generally Wadlington, Adoption of Adults in Louisiana, 40 TUL. L. REv. 1 (1965).

70 Texas enacted an adoption statute in 1850. Dic. LAws of TEx. 88 (Fartley 1850). Very simple in form, it specifically hited the inheritance rights of an adopted child in the event that there were legitimate blood children born to the adopter before or after the adoption. The act speaks almost wholly in terms of adoption as a "legal heir."

${ }^{77}$ See Eckford v. Knox, 67 Tex. 200, 204, 2 S.W. 372, 374 (1886).

${ }^{78}$ E.g., Ross v. Ross, 129 Mass. 243, 262 (1880); Morrison v. Estate of Sessions, 70 Mich. 297, 306-07, 38 N.W. 249, 253 (1888); In the Matter of Livingston, 151 App. Div. 1, 2, 135 N.Y. Supp. 328, 329 (1912).
} 
United States. Greater influence is seen in the laws of Puerto Rico, however, where a sixteen-year age difference between adopter and adoptee is required-unless the adopter has been married to the adoptee's father or mother for at least five years at the date when the adoption petition is filed. ${ }^{79}$

\section{B. The Massachusetts Statute of 1851}

Frequently referred to as the earliest of indigenous United States adoption laws, ${ }^{80}$ the Massachusetts statute of $1851^{81}$ made no reference to a minimum age difference between adopter and adoptee. This statute, which remained the nucleus of the Massachusetts adoption law for over half a century, was used as a model for the drafting of early adoption legislation in a number of other states. ${ }^{82}$

\section{The Field Code}

The 1865 Civil Code of New York, widely known as the Field Code, ${ }^{83}$ exerted a profound influence on the private law of a number of western states, even though it was never adopted in New York itself. ${ }^{84}$ Though not included in the earlier published draft, ${ }^{85}$ the 1865 code contained fairly comprehensive provisions on the law of adoption, and required that "the person adopting a child must be at least twenty years older than the person adopted ...."88 This provision was incorporated, for example, into the California Civil Code in 1871 with a reduction in the required age variation to fifteen years. ${ }^{87}$ In 1874 the age difference was reduced to ten years. ${ }^{88}$

\footnotetext{
${ }^{79}$ P.R. LAws ANN. tit. 31, §531 (1955).

80 The Texas statute mentioned in note 76 supra was enacted a year earlier. Missis. sippi had a provision for making an heir of one who was a stranger to the family as early as 1846. Miss. Laws 1846, ch. 60, also cited in Miss. Cone ch. 35, art. 2 (Hutchison 1848). But neither of these statutes was nearly so detailed or complete as that of Massachusetts, and it is even questionable that they should be considered as adoption statutes at all, in the present sense of the word.

81 Mass. Gen. Laws 1836-1853, ch. 324, at 752 (1854).

${ }^{82}$ For a judicial discussion of the influence of the Massachusetts statute on the laws of Wisconsin and Illinois, see Keegan v. Geraghty, 101 Ill. 26, 33 (1881).

88 Commissioners of the Code, Civil Code of the State of New York (1865). David Dudley Field was among the Commissioners, who had been appointed pursuant to the Act of April 6, 1857, I N.Y. Laws ch. 266 (1857). In theory the code represented a civilian approach to codification, though the existing common law was said to form its substantive base. Commissioners of THE CODE, op. cit. supra at iii-iv.

${ }^{8}$ New York did enact an adoption statute in 1873 , but it contained no requirement of an age difference between adopter and adoptee. N.Y. Laws ch. 830 (1873).

s5 Commissioners of the Code, Draft of a Civil Code for the State of New YORK (1862).

${ }^{86}$ Commissioners of the Code, Civil Code of the State of New York $§ 108$ (1865).

87 CAL. Crv. CODE $§ 222$ (1871).

${ }^{88}$ Amendments to Codes of Cal. 1873-1874, § 48, at 813.
} 
This ten-year age difference in the California statute apparently formed the original model for similar provisions in other western territories and states, including Arizona, ${ }^{89}$ Montana, ${ }^{90}$ Nevada, ${ }^{91}$ New Mexico, ${ }^{92}$ North Dakota, ${ }^{93}$ and Utah. ${ }^{94}$ Idaho adopted the original California requirement of an age difference of fifteen years. ${ }^{95}$

\section{The Uniform Adoption Act}

Though formally adopted to date in only two states, Montana ${ }^{98}$ and Oklahoma, ${ }^{97}$ the Uniform Adoption Act $^{88}$ has clearly exerted strong influence in a number of others. ${ }^{99}$ It specifies no minimum age difference for minor adoptions. Consensus of the Commissioners against including such a requirement has been explained on the basis that "years alone do not qualify one for parenthood."100 However, the Uniform Act does list an optional age difference requirement in the case of adult adoptions. ${ }^{101}$

Ironically, the two states which have adopted the Uniform Act both had minimum age difference requirements which were eliminated on passage of the Uniform Act. ${ }^{102}$

\section{E. Other Influences}

In addition to the four influential approaches mentioned above, some states developed varying adoption statutes independent of these factors, often at a very early date. The Uniform Adoption Act has not been the only legislative guide. The Children's Bureau of the U.S. Department of Health, Education and Welfare, for ex-

\footnotetext{
${ }^{80}$ ARIZ. REv. Stat. $\$ 2037$ (1901).

${ }^{\circ}$ Mont. Comp. Stat. div. 5, ch. 1, $\$ 2$, at 587 (Supp. ed. 1888).

$01 \mathrm{Nev}$. Stats. 1885 , ch. $24, \S 1$. This section did provide, however, that if a husband and wife were adopting a child, only one of them need be ten years older.

${ }^{\circ 2}$ N.M. CoMp. Laws $\$ 1497$ (1897).

${ }^{93}$ N.D. REv. CODES § 2798 (1895).

Q UTAF REV. STAT, tit. 1, § 2 (1898).

${ }^{25}$ IDAFO REV. CoDEs $\$ 2546$ (1887).

${ }^{\circ 0}$ MoNT. Rev. CODEs ANN. $\$ \S 61-201$ to -218 (1962), as amended, MONT. REv. Codes ANN. $\$ \$ 61-211$ to -212 (Supp. 1965).

of OKLA. STAT. ANN. tit. 10, \$§ 60.1-.23 (Supp. 1964).

os The Uniform Act was promulgated in 1953 by the National Conference of Commissioners on Uniform State Laws.

${ }^{\circ}$ See, e.g., S.C. Code AnN. $\$ \S 10-2587.1$ to .18 (Supp. 1965); Wyo. Stat. ANN. §§ $1-707.1$ to -711.2 (Supp. 1965).

${ }^{100}$ Merrill \& Merrill, Toward Uniformity in Adoption Law, 40 IowA L. REv. 299, 303 (1955).

${ }^{102}$ UNIFORM ADOPTION Act § 18. The bracketed, optional age difference is ten years. ${ }_{102}$ The superseded provisions are cited in MONT. REV. CODES ANN. $\S 61-128$ (1947), and OKLA. Stat. ANN. tit. 10, $\$ 42$ (1941).
} 
ample, has published suggested legislative language for "An Act for the Adoption of Children," 103 which contains no requirement of an age difference between adopter and adoptee. However, the four influences mentioned above appear to have been the most important with regard to the inclusion or omission of a required minimum age difference.

\section{IV}

\section{The Present Situation in the United States}

Adoption is a matter for individual state regulation in this country, and despite various attempts to encourage uniformity, the approaches vary greatly from state to state. This is especially true with regard to requiring a minimum age variation between adopter and adoptee. Some states have no requirement of a specific age difference, but do require that the adopter must be "older" than the adopted person, ${ }^{104}$ or that the adopter must be a major in order to adopt a minor. ${ }^{105}$ Twelve states now require a specific age difference. ${ }^{106}$ Within this group there are variations in the specific difference in ages; in whether the requirement applies only to adoption of minors, or to adoption of adults, or to both; and in exceptions allowed in specific situations, such as when the adopter is married to the blood parent.

Of these twelve states which require a specific difference in age, ten apply the requirement to adoption of minors. ${ }^{107}$ Eight specify an age difference of ten years and two specify fifteen years. ${ }^{108}$ Only six of these twelve states apply any specific age difference provision

\footnotetext{
${ }^{103}$ See Children's Bureau, U.S. Dep'T. OF Health, Education and Welfare, Legislative Guides for the Termination of Parental Rights and Responsibilities and the ADOptIon OF CHILDREN 49-61 (1961).

${ }^{104}$ E.g., Conn. Gen. Stat. AnN. \$ 45-67 (1964); Mass. Ann. Laws ch. 210, § 1 (1955).

${ }^{105}$ E.g., Fua. STAT. ANN. $\$ 72.11$ (1964).

${ }^{100}$ By use of the term "specified age difference" or words of similar import, it is meant to include only statutes which require a minimum of some fixed number of years in age separation. This does not include statutes which require that the adopter need merely be "older" than the adoptee, or that the adopter must be a major and the adoptee a minor. The states with specified age difference requirements applicable to some or all of their adoption provisions are Arizona, California, Florida, Georgia, Idaho, Nevada, New Jersey, New Mexico, North Dakota, South Dakota, Utah, and West Virginia. The provisions of the individual statutes within each of these states are discussed in greater detail in the Appendix infra.

${ }_{107}$ These are Arizona, California, Georgia, Idaho, Nevada, New Jersey, North Dakota, South Dakota, Utah, and West Virginia. See the Appendix infra.

${ }^{108}$ Except for Idaho and West Virginia, which require an age difference of fifteen years, each of the states listed in note 107 supra specifies a ten-year age spread as mandatory.
} 
to adoptions of adults. ${ }^{100}$ Three require a ten year difference, ${ }^{110}$ two require a fifteen year difference, ${ }^{111}$ and one requires a difference of twenty years. ${ }^{112}$

Although the fact that fewer states have age differential requirements for adoption of adults than for adoption of minors can be explained in part by the fact that not all states permit adoption of adults, this is by no means the only reason for such a substantial variation in the figures. Several jurisdictions which permit adoption of both minors and adults have age variation requirements which apply only to one or the other category of adoption. ${ }^{113}$ Four states, however, have required variations for adoption of both majors and minors. ${ }^{114}$ Yet even one of these states provides a different age variation for adult adoptions than for minor adoptions. ${ }^{115}$

Where a minor is being adopted, at least one other factor becomes material. This is the almost universal provision for exercise of discretion by the trial judge in determining whether an adoption will be in the best interests of the adoptee. Even in states which require no specific age differential, a judge may nevertheless be empowered to grant or deny an adoption on the basis of the fairly vague test of the child's best interest; that age may be a factor for his consideration is at least suggested by the statutory requirement in many states that the petition for adoption must include both the age of the party to be adopted and the age of each prospective adopter. ${ }^{116}$ But since the party to be adopted has frequently lived in the home of the adopter for some time, the judge, in weighing how best to exercise his discretion, might in the child's best interest overlook the closeness of age in order to avoid

${ }^{100}$ Florida, Idaho, New Jersey, New Mexico, North Dakota, and Utah (which has only a limited provision for adoption of adults). Nevada and California, which have required age differences for adoption of minors, require that in adoption of adults the adopter must be "older" than the adoptee.

ג20 Florida, North Dakota, and Utah.

112 New Jersey, which only requires a ten year age difference in adoption of minors, increases the required age spread to fifteen years in adoption of adults. Idaho's fifteen year difference seems to apply to adoption of adults as well as adoption of minors.

112 New Mexico, which now has no requirement of a specific age difference in adoption of minors, requires a twenty-year age difference in adoption of adults.

${ }_{113}$ These include California, Nevada, and West Virginia (and probably Georgia), with fixed age difference statutes applicable only to adoption of minors, plus Florida and New Mexico, which have such provisions applicable only in adoption of adults. 11< Idaho, New Jersey, North Dakota, and Utah.

${ }_{115} \mathrm{New}$ Jersey requires a ten-year age difference for minor adoptions and a fifteenyear age difference for adult adoptions.

${ }^{110}$ E.g., Fla. STAT. ANN. \$ 72.12 (1964); La. Rev. STat. tit. 9, § 424 (1965). 
returning the child for a second placement, even though he would have frowned on permitting such a placement initially. This, of course, places the problem squarely in the lap of the placing individual or agency. And although many agencies may make it a practice to require a minimum age spread, there may be no legal requirement that they do so. ${ }^{117}$ Further, in the case of the private placement, there are all too often no restraints or even guidelines for gauging the likelihood of effective placement.

In summary, it would seem that there are at least some restraints in most states on the too-close-together-in-age adoption. In the case of adult adoptions, the restraint can be found only in the form of specific statutes. In the case of minor adoptions, the restraint may be a specific statutory one or, more frequently, a discretionary provision. However, very few cases have actually been litigated in appellate courts over this issue ${ }^{118}$ and the recent statutory trend, if there is one, is toward elimination of mandatory age difference for adoption in this country. ${ }^{110}$

\section{$\mathrm{V}$}

Some Lessons from Comparison: Should an Age

DifFERENCE Be ReQuired?

It is difficult to explain the dichotomy between civil law jurisdictions and our own states regarding the requirement of a minimum age variation between adopter and adoptee. In the civil law jurisdictions, the emphasis of adoption law traditionally has revolved around providing an heir for the adopter, or gratifying the personal desires of childless parents in their declining years-in other words, adoption has focused on the interests of the adopter, rather

117 The administrative regulations for the licensing of placement agencies sometimes include such provisions. For example, in Louisiana these regulations require each agency to make a study of the adoptive home. The written record of the study must show that "the adoptive parents are of an age that they could be the child's natural parents." LA. Dep't. of Public Welfare, Minimum Requirements for License of Child Placing Agencies 23-24 (1959).

${ }^{218}$ Generally, the cases that do take up the issue indicate that the courts will construe the provisions strictly. E.g., Hendy v. Industrial Acc. Bd., 115 Mont. 516, 519, 146 P.2d 324, 325 (1944). In some the requirement is described as jurisdictional. In the Matter of Estate of Sbaron, I79 Cal. 447, 454, 177 Pac. 283, 286 (1918); Estate of Summers, 51 Cal. App. 2d 39, 44-45, 124 P.2d 94, 97 (Dist. Ct. App. I942). But cf. Gravelin v. Porier, 77 Mont. 260, 279, 250 Pac. 823, 828 (1926).

119 There probably has not been enough legislative activity recently to establish any real trend. But the promulgation of the Uniform Adoption Act without a required age difference and its acceptance in two states which formerly had required age variations has thinned the ranks somewhat. See notes 96.99 supra and accompanying text. 
than on the interests of the adoptee..$^{120}$ This emphasis is due to the influence of Roman adoption concepts on civil law. Additionally, the basic Roman principle of adoptio naturam imitatur has carried through to modern civil law, and this explains the minimum age provisions in most civil law statutes. Importantly, these provisions are generally applicable without regard to the age of the adoptee or the motives which led to adoption. Adult adoptions were not uncommon in Roman times, and in the original French code there was no provision for adoption of a person before he had attained majority..$^{121}$

\section{A. Adoption of Minors}

When the emphasis is shifted to the needs of the adoptee, the wisdom of the "adoption imitates nature" principle seems to be even clearer. With respect to adoptions of minors in this country, courts and legislatures have repeatedly proclaimed that the institution is designed chiefly to serve and protect the interests and welfare of the person adopted. ${ }^{122}$ In fact, courts in this country may refuse to recognize adoptions from countries where the institution is not so oriented. ${ }^{123}$ Given our ostensible desire to make the adopted child as much a member of the adopting family as possible-to duplicate closely the natural parent-child relationship through this artificial, legal process-it would seem that our adoption laws would be most concerned with placing a child only in a biologically-possible age relationship, rather than in one where it is obvious that he could not be the natural child of the adopter.

Of course, the possibility of extremely close age difference between the adopter and a minor adoptee is minimized in most cases

${ }^{220}$ For a look at the various ends which adoption has served in history, see HamiltonGrierson, An Example of Legal Make-Believe, 21 JuRD. REv. 17 (1909); Huard, The Law of Adoption: Ancient and Modern, 9 VAND. L. Rev. 743 (1956).

121 See Code Civil art. 346 (Fr. 1803).

${ }_{122}$ Cases which have so stated include Adoption of Thevenin, 189 Cal. App. 2d 245, 252, 11 Cal. Rptr. 219, 224 (Dist. Ct. App. 1961); In the Matter of Brock, 157 Fla. 291, 294, 25 So. 2d 659, 661 (1946); Fowler v. Sutton, 222 Miss. 74, 76, 75 So. 2d 438, 439 (1954); In re Adoption of Blachinsky, 127 N.Y.S.2d 553, 554 (Surr. Ct. 1953); In re Adoption of List, 418 Pa. 503, 515, 211 A.2d 870, 877 (1965).

Statutes which so provide include CAL. Crv. CODE $\S 227$ (Supp. 1965); D.C. CoDE ANN. § 16-218 (b) (3) (1961); FLA. STAT. ANN. § 72.20 (1964); N.Y. DoM. REL. LAW \$§ 114, 116 (4); Pa. STat. AnN. tit. 1, \& 4 (1963).

${ }_{123}$ See, e.g., In the Matter of Estate of Gillies, 8 N.J. 88, 83 A.2d 889 (1951); Doulgeris v. Bambacus, 203 Va. 670, 127 S.E.2d 145 (1962), 49 VA. L. REv. 1424 (1963). Non-recognition of adoptions because of dissimilarity in approaches is criticized strongly in Taintor, Adoption in the Conflict of Laws, 15 U. PITT. L. REv. 222 (1954). 
by the discretionary function of the judge and by the administrative regulations and procedures of various placement agencies. ${ }^{124}$ There are still a substantial number of instances, however, where this will not be true. If a minimum age difference is in fact desirable, what objection is there to legislation which would assure that such a difference will be maintained in all cases? This not only would be in keeping with the ostensible purpose of our adoption laws, but also would constitute express approval of this purpose.

\section{B. Adoption of Adults}

Is it necessary to provide a minimum age difference for adult adoptions? There is little authority available to answer this question because interest and practice in this country have centered on adoption of minors. Thus, appellate decisions concerning adoption of adults are lacking, ${ }^{125}$ the legal literature on the subject is sparse, and a number of states still permit only minors to be adopted. ${ }^{126}$ On the basis of the usual procedural differences between adoptions of adults and minors, along with the greater emphasis on benefits to the adoptee which is found in minor adoptions, it could be argued that adult adoptions should be regarded as sui generis in our law, and that requirements for a minimum age difference, even though properly applicable to adoptions of minors, should not be imposed when an adult is being adopted. The arguments on both sides of this proposition must be carefully considered.

First, not all of the factors which seemingly dictate a need for a minimum age difference in the case of adoptions of minors would be applicable to adoptions of adults. For example, in the latter instance there is little chance of any deep psychic scarring of the adoptee when he is obviously aware that the general public will know that he could not be the adopter's blood child but he has nevertheless consented to the adoption. The situation is much different in the case of the infant who is placed in an adoptive home through a judicial proceeding in which the records of trial are ac-

\footnotetext{
${ }^{124}$ See notes 116-17 supra and accompanying paragraph.

${ }^{125}$ The small number of appellate cases on adoption of adults have often questioned the public policy of permitting adoption when the parties occupy certain personal relationships, or have attacked the competency or free consent of the adopter. See, e.g., Greene v. Fitzpatrick, $220 \mathrm{Ky}$. 590, 295 S.W. 896 (1927); Collamore v. Learned, 171 Mass. 99, 50 N.E. 518 (1898); Russell Adoption Case, I66 Pa. Super. 590, 73 A.2d 794 (1950); Annot., 56 A.L.R.2d 823, 824-27 n.9 (1957).

${ }^{126}$ For example, Arizona and South Dakota allow adoption only of minors. See the Appendix infra.
} 
corded great confidentiality ${ }^{127}$ and after which a substitute birth certificate may be issued to indicate that the adopters are in fact the blood parents of the adopted child. ${ }^{128}$

A second consideration rendered unimportant in adult adoptions is the need for determining the desirability of the adoptive home as a place for the cultural, intellectual, and physical growth of the adoptee. Factors ranging from the educational background of the parents to their ability to provide financially for the child are clearly relevant in minor adoptions; it is in order to consider such factors that judicial supervision is almost universally required. These factors generally need not be taken into consideration in adult adoptions. Unless the adoptee is under a disability, there probably will be no legal duty for the adopter to provide financial assistance except in cases in which an adoptee becomes destitute. The adoptee may not even live with the adopter after the adoption. Aside from love and affection or possible financial gain to either adopter or adoptee, the motives for adoption of an adult may range from spite to ego massage; ${ }^{129}$ whether the adoption would be in the adoptee's best interests is (as generally required for adoption of a minor) irrelevant when only the consent of adopter and adoptee is necessary to effectuate the adoption.

The prime reason for deciding that none of these arguments should prevail is rooted in the definition of adoption as the institution is known to us. In our present system adoption is designed to create through artificial means something resembling as closely as possible a normal parent-child relationship and not a freak or totally new form of relation. If in fact adoption of adults is designed to accomplish something different, then such a purpose should be expressed clearly in the enabling statutes. But this is not the case at present. Despite the variations in procedure between adult and minor adoptions, adoption of an adult generally will accomplish most or all of the civil effects that will be achieved through adoption of a minor. The desirability of this has been questioned judicially, ${ }^{130}$ but as yet there seems to be no major legislative movement to ex-

\footnotetext{
${ }^{127}$ Some statutes specifically require confidentiality in adoption proceedings. E.g., Uniform Adoption Act § 13; N.C. Gen. Stat. § 48-25 (Supp. 1963).

${ }^{128}$ Substitute birth certificate requirements are found, for example, in UNIFORM Adoption Acr optional § 14, and N.G. GEN. STAT. § 48-29 (Supp. 1965).

${ }^{120}$ See note 6 supra.

${ }^{130}$ See, e.g., Wilson v. Johnson, 389 S.W.2d 634, 636 (Ky. 1965).
} 
pand or change the institution of adoption of adults; if anything, it is still being ignored.

Without a normal age gap between adopter and adoptee, the result of assimilation closely to the normal parent-child relationship will not be accomplished. It was on this theory that the Romans (who also permitted adoption in relationships other than parentchild, such as grandparent-grandchild ${ }^{\mathbf{1 3 1}}$ ) applied the adoptio naturam imitatur concept without regard to the age of the adoptee. The reasoning is equally applicable today. The importance of statutory regulation in this regard for adult adoptions is particularly great because of the simplicity of most state adult adoption procedures. ${ }^{132}$

VI

\section{What Legislation Is REQuired?}

In reviewing the various statutes both here and abroad, two approaches emerge which would be legally feasible, with some variations or exceptions possible within the framework of each. The first approach would be to require a specified age difference between adopter and adoptee, perhaps combined with elimination or relaxation of the restriction when the person to be adopted is the blood child of the prospective adopter or his spouse. The second approach would be to set a high minimum age requirement for the adopting party and permit only adoption of minors. If the minimum age were set at thirty, for example, at least a ten-year age difference would be assured. A variation on this approach would be to allow adoption of minors only up to a certain age-say fifteen years-and only by persons over twenty-five years of age.

The second approach would restrict the available pool of adopters considerably. Such an approach seems even more objectionable because placements are frequently made when the adoptee is extremely young-particularly where an adoption agency is involved-and thus the age difference between parent and child might be undesirably great. ${ }^{133}$ The alternative of lowering the maximum age

${ }^{131}$ See Buckland, A Textbook of Roman Law 123 (3d rev. ed. 1963).

132 Of course, more rigorous control of adult adoptions or complete abolition of the institution are additional possibilities. See notes 8-9 supra and accompanying text. Nevertheless, a required age difference would partially alleviate the problems of abortive adult adoptions.

${ }^{133}$ For expert opinions that great disparity in age between adopters and adoptee is inimical to the child's best interests, see Brunt v. Watkins, 233 Miss. 307, $101 \mathrm{So}$. 2d 852 (1958) (prospective parents aged fifty-three and fifty-one; prospective adoptee aged three). 
for adoption to fifteen would obviate that problem but would nevertheless eliminate the adoption of children over fifteen-a result contrary to the recent judicial awakening to the need for parental aid and assistance for children even beyond their majority ${ }^{134}$ and the legislative trend to relax the requirement of parental consent ${ }^{135}$ which has often thwarted adoption of the older neglected child. Some form of the first approach, which, incidentally, is the type of approach taken by the civil law, thus seems to be preferable because none of these objections is applicable.

\section{A. What Should Be the Required Age Difference?}

The Roman law requirement of an eighteen-year age difference between adopter and adoptee was based on the latest time at which the male could be considered to have reached puberty. ${ }^{136}$ Eighteen years is greater than the generally accepted age of puberty for males

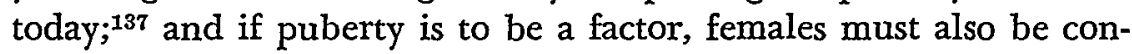
sidered since today they legally may adopt in most, if not all, states. If the age difference now were to be based solely on the reaching of puberty, further questions would be raised. Should the minimum, average, or latest age for reaching puberty be used? Should there be a different age variation requirement for male and female adopters? In view of these problems and other possible variables, ranging from geography to difference in ethnic groups, a strict puberty test would seem impractical today.

One possible alternative would be to use the minimum age for marriage in computing the required age variation for adoption. ${ }^{138}$

\footnotetext{
${ }^{134}$ A growing trend toward requiring contribution toward college expenses-even though the child may be past majority-is one illustration of this phenomenon. See Crane v. Crane, 45 Ill. App. 2d 316, 322-27, 196 N.E.2d 27, 30-33 (1964) (dissenting opinion), and authorities cited therein.

${ }^{135}$ See, e.g., VA. Code ANn. \$ 63-351 (4) (Supp. 1964).

${ }^{230}$ See text accompanying notes 23-24 supra.

${ }^{137}$ Puberty is defined from a medical standpoint today as "the age of a person during which the sex and reproductive organs begin to function and become effective, and the secondary sex characteristics develop." SchMitd, ATtorneys' Dictionary of Medicrne 656 (1965). Though most medical texts do not speak in terms of exact age, it is probably agreed that the average age of puberty, which falls in the middle of adolescence, is between twelve and fourteen for females and fourteen and sixteen for males. See Stuart \& Prugh, The Healthy Child 4, 6-7 (1960).

${ }^{138}$ The very existence of such minimum age statutes is strong argument in favor of a minimum age difference between adopter and adoptee, in order that the latter will not appear to have been born at a time when the adopting parents legally could not have been married. This must be tempered somewhat, however, by the fact that many adopted children are illegitimate-often born to mothers below marriageable age.
} 
Again, the variations within most states between the provisions for men and women on marriageable age must be considered. ${ }^{130}$ Additionally, age for marriage is by no means based simply on development of the reproductive capacity of the parties; there are a considerable number of age variations between states; ${ }^{140}$ and there is judicial confusion as to the minimum age at which a marriage will be considered voidable or void.141

Probably the best answer is a compromise: a mandatory age variation within the realm of biological probability and within or near legal possibility as well, at least to the extent of a voidable rather than a void marriage. It is submitted that the most acceptable compromise, applying these standards, would call for a fifteen-year age variation.

\section{B. What Exceptions Should Be Permitted?}

In an institution which is clearly artificial to begin with, there is always the possibility of creating exceptions, if the purpose for such exceptions is socially desirable. Probably the two exceptions which would be most universally accepted would involve (1) the remarriage of a natural parent and the desire of the new spouse to adopt his spouse's child, ${ }^{142}$ and (2) the desire of a natural parent to adopt his own illegitimate child. ${ }^{143}$ In such cases there is a clear, biological separation between the adoptee and at least one parent in all cases. However, it is submitted that there is still no good reason to eliminate entirely the age separation requirement except in situation (2). Otherwise we could easily envision the bizarre-though not unusual-case of a seventy-year-old man with a forty-year-old daughter marrying his thirty-year-old secretary who then desired to adopt her husband's child-a child ten years her

${ }^{130}$ The following statutes, for example, provide minimum ages of twenty-one and eighteen for males and females to be married without parental consent: ILL. REv. STat. ch. 89, § 3. (1965); Mass. GEN. LAws ANN. ch. 207, § 7 (1955); N.Y. Dom. REL. LAW § 15 .

${ }^{140}$ For example, Georgia provides minimum ages of eighteen and sixteen for marriage by males and females with parental consent (GA. Code ANN. \$ 53-102 (Supp. 1965)), while the corresponding ages in New York are sixteen and fourteen (N.Y. DoM. REL. LAw § 15). Without parental consent, the minimum age for both males and females is twenty-one in Connecticut (CONN. GEN. STAT. ANN. \$ 46-5 (1958), and only nineteen in Georgia (GA. Code ANN. \$ 53-204 (Supp. 1965)).

${ }^{141}$ See 55 C.J.S. Marriage $\$ 11$ (1948).

${ }^{142}$ Such an exception is already made in the statutes of Idaho and West Virginia. IDAHo CODE ANN. §16-501 (Supp. 1965); W. VA. CodE $\S 4756$ (1961).

${ }_{143}$ This would only be necessary, however, for cases in which there is no pro. vision for legitimation, or where such provisions are extremely limited in scope. 
senior. If we are to continue our basic approach of trying to assimilate the institution of adoption as closely as we can to the natural parent-child relationship, we may lower the age difference to no less than ten years. Even if we wish to eliminate the puberty consideration entirely for policy reasons, it still seems that an age difference of ten years would be in order. ${ }^{144}$ Perhaps the best way to handle situation (l) would be to adopt the approach to the original English statute, which merely gave the judge discretion to lower the age variation requirement if circumstances warranted it. ${ }^{145}$

\section{VII}

\section{Is There a ReAL NEEd for Legislation?}

Adoption is a relatively narrow institution; to permit its expansion beyond the narrow bounds for which it was accepted into our law is to weaken it. When it becomes obvious that adoption purely for tax advantage or inheritance purposes is available, the entire institution can be damaged.140 If we want adoption to continue as a socially useful institution, we should not tolerate abortive uses to be made of it. Legislation seems to be the logical preventive against such uses; and immediate legislation, before these unsavory practices become widespread, would seem to be a wise course.

146 Of course, one justification for a ten-year separation would be the fact that this is presently the most popular age variation found among states which have any required age difference other than simply "older." See the Appendix infra.

${ }^{145}$ See pt. II of this article supra. It is not suggested that the originally unclear drafting of the English statute be followed.

${ }^{160}$ As one judge has put it: "The increased frequency with which these cases are arising raises the question of whether, as the word gets around, there will be more adoption or treasure hunts as they may be called which take advantage of the provision in a will wherein an estate is left for life with remainder to children, heirs, etc. In every such instance where there are no children or heirs, the way has been opened by use of adoption to take advantage of the testator and his estate." Wilson v. Johnson, 389 S.W.2d 634, 637 (Ky. 1965) (Montgomery, J., dissenting). 


\section{APPENDIX}

\begin{tabular}{|c|c|c|}
\hline \multirow[b]{2}{*}{ State } & \multicolumn{2}{|c|}{ Required Age Difference } \\
\hline & Minors & Adults \\
\hline Ariz. & $10^{1}$ & 一* \\
\hline Cal. ${ }^{2}$ & $10^{3}$ & older ${ }^{4}$ \\
\hline Fla. & none ${ }^{5}$ & $10^{8}$ \\
\hline Ga. & $10^{7}$ & unclear $^{8}$ \\
\hline Idaho $^{\theta}$ & $15^{10}$ & $15(?)^{11}$ \\
\hline Nev. & $10^{12}$ & older ${ }^{13}$ \\
\hline N. J. & $10^{14}$ & $15^{15}$ \\
\hline N. M. & none $e^{16}$ & $20^{17}$ \\
\hline N. D. & $10^{18}$ & $10^{19}$ \\
\hline S. D. & $10^{20}$ & 一* \\
\hline Utah & $10^{21}$ & $10^{22}$ \\
\hline W. Va. & $15^{23}$ & none $^{24}$ \\
\hline
\end{tabular}

- No statutory provision for adult adoptions.

1 ARiz. Rev. Stat. ANN. § 8-101 (1956).

"An illegitimate child can be "adopted" (actually legitimated) by acknowledgment and conduct of natural parent, with no required age difference. CAL. Crv. CoDE $\$ 230$.

${ }^{2}$ CAL. Civ. Code $\S 222$.

- CAL. CIv. CoDE $\$ \S 221,227 \mathrm{p}$.

${ }^{8}$ Fla. Stat. AnN. $\$ 72.11$ (1964).

${ }^{\circ}$ FLA. Stat. ANN. $\$ 72.34$ (1964).

${ }^{7}$ GA. Code ANN. \& 74-402 (Supp. 1962).

${ }^{8}$ No specific age difference is required by the adult adoption provision. GA. CoDE ANN. \& 74-420 (Supp. 1962). Yet the age difference requirement for minors, while located within the general provisions for minor adoptions, uses the term "child" rather than "minor child," which could be interpreted to mean that it applies to adults as well. GA. CoDE ANN. $\$ 74-402$ (Supp. 1962).

-An "adoption" (legitimation) provision similar to California's (note 2 supra) is found in IDAHO CODE ANN. \$ 16-1510 (Supp. 1965).

${ }^{10}$ IdAho CODE ANN. $\$ 16-1502$ (Supp. 1965). The requirement is waived where the adopter's spouse is tbe natural parent. Ibid.

${ }_{11}$ Adoption of adults is narrowly limited, and it is unclear whether the fifteen-year age requirement is applicable. IDAHo CodE ANN. $\$ 16-1501$ (Supp. 1965).

12 NEv. REv. Stat. \$ 127.020 (1963).

13 NEv. REv. Stat. $\$ 127.190$ (1963). Adoption of spouses is forbidden. Ibid.

${ }^{14}$ N.J. REv. Stat. § 9:3-22 (1937).

${ }^{15}$ N.J. Rev. Stat. \$ 2A:22-2 (1937).

${ }^{16}$ See N.M. Stat. ANN. $§ 22-2-1$ (1953).

${ }^{17}$ N.M. StAT. ANN. $\S 22-2-13$ (1953).

${ }^{18}$ N.D. CENT. CODE $§$ 14-11-02 (1960).

19 N.D. CENT. CODE § 14-11-08 (1960).

${ }^{20}$ S.D. CODE $\S 14.0401$ (1939).

21 UTAH CODE ANN. \& 78-30-2 (1953).

22 Ibid. Both natural parents of adults must be deceased before he can be adopted. UTAH CODE ANN. § 78-30-1 (1953).

${ }^{23}$ W. VA. CODE ANN. $\S 4756$ (1961). The requirement is waived where the adopter's spouse is the natural parent. Ibid.

s\$ See W. VA. CODE ANN. $\S 4760$ (1) (1961). 